\title{
Pelatihan Penggunaan Google Classroom Dan Google Meet Sebagai Media Digital Untuk Pembelajaran Daring Selama Pandemi Covid- 19 Bagi Guru- Guru Di SDIT ALIF
}

\section{Cici Handayani' ${ }^{1}$ Dewi Wulandari², Sharina Amanda ${ }^{3}$, Zakia Fadila $^{4}$, Muhammad Fathoni ${ }^{5}$}

\author{
${ }^{1}$ Sekretari \\ 2,3,4 Akuntansi, Manajemen Informatika ${ }^{5}$ \\ Politeknik Unggul LP3M Medan, JI. Iskandar Muda No.3 CDEF, Medan, Sumatera Utara, \\ Indonesia \\ Email: cici.handayani@gmail.com
}

Abstrak

\begin{abstract}
Pelaksanaan pembelajaran jarak jauh merupakan proses pembelajaran yang dilakukan secara daring/ online oleh pihak sekolah- sekolah baik di Indonesia maupun di negara- negara yang masih terkena dampak pandemic Covid-19. Pandemic ini memaksa kalangan dunia pendidikan untuk tidak menyelenggarakan proses belajar tatap muka dikelas-kelas. Hal ini mengakibatkan proses pembelajaran menjadi tidak efektif terlebih lagi masih banyak guru atau tenaga pendidik yang tidak memanfaatkan teknologi untuk mendukung pembelajaran jarak jauh ini. Sedangkan, tersedia begitu banyak aplikasi yang dapat digunakan untuk itu. Diantaranya adalah aplikasi Google Classroom dan Google Meet. Kedua aplikasi ini belum digunakan secara efektif oleh tenaga pendidik dikarenakan keterbatasan pengetahuan dalam penggunaannya yang masih dianggap sulit.Melalui pelatihan yang dilaksanakan pada tanggal 3 Juli 2021 ini di SDIT Alif, para tenaga pendidik diperkenalkan dan dilatih secara detail bagaimana memanfaatkan aplikasi Google Classroom dalam memberikan tugas dan penilaian kepada para siswa dan juga menggunakan Google Meet secara efektif dalam menyampaikan materi ajar. Setelah mengikuti pelatihan ini, para tenaga pendidik memiliki pengetahuan lebih baik dan lebih detail lagi mengenai penggunaan aplikasi Google Classroom dan Google meet ini sehingga langsung dapat menerapkan penggunaan kedua aplikasi ini dalam proses belajar mengajar jarak jauh dalam masa pandemic Covid- 19 ini.
\end{abstract}

Kata Kunci: Pelatihan, Google Classroom, Google Meet

\section{Pendahuluan}

Terhitung sejak Desember 2019, Indonesia menjadi salah satu negara yang terkena dampak pandemic COVID- 19 yang mewabah diseluruh dunia. Pandemic ini berdampak parah terhadap semua aspek kehidupan termasuk aspek pendidikan dimana semua proses pembelajaran yang seharusnya dilaksanakan disekolah- sekolah menjadi dilaksanakan secara daring. Begitu juga dengan sector pekerjaan yang seharusnya dilaksanakan di perkantoran menjadi pekerjaan yang dilakukan dirumah atau lebih dikenal dengan istilah WFH (Work From Home). Kondisi ini memaksa setiap individu yang terlibat untuk menggunakan teknologi yang ada sekarang seperti pemanfaatan gadget atau aplikasi- aplikasi yang dapat dimanfaatkan untuk mendukung setiap pekerjaan atau tugas yang dilakukan. Seiring dengan kemajuan teknologi sekarang ini, ada begitu banyak aplikasiaplikasi yang diciptakan untuk memudahkan pekerjaan. Salah satunya adalah aplikasi yang diciptakan oleh perusahaan multinasional dalam bidang internet, Google. Pihak Google telah menyematkan aplikasi Google Classroom dalam dunia internet.Google Classroom ini merupakan layanan web gratis yang dikembangkan oleh pihak Google untuk digunakan dalam dunia pendidikan khususnya bagi guru dan siswa. Dengan menggunakan Google Classroom, seorang guru dapat membuat, mendistribusikan dan menilai tugas siswa- siswanya tanpa harus melakukan tatap muka. 
Penggunaan Google Classroom selama masa pandemic ini dinilai sangat efektif karena proses belajar mengajar tidak perlu dilakukan secara langsung dikelas atau istilahnya pembelajaran tatap muka. Sedangkan, untuk proses pembelajaran tatap muka selama masa pandemic ini dapat dilakukan dengan menggunakan aplikasi Google Meet yang merupakan aplikasi meeting online. Google Meet tidak hanya digunakan oleh para pekerja kantoran yang harus bekerja dari rumah, tetapi banyak juga digunakan dalam bidang pendidikan terutama untuk interaksi tatap muka secara daring antara guru dengan siswa- siswanya dalam menyampaikan materi pembelajaran. Dan juga dapat digunakan untuk seminar- seminar online atau lebih dikenal dengan istilah webinar. Aplikasi ini dapat digunakan memalui computer, laptop maupun telepon seluler berbasis android.

Sayangnya, penggunaan aplikasi Google Classroom dan Google Meet ini belum begitu dapat digunakan secara efektif dikarenakan keterbatasan pengetahuan dalam menggunakannya. Terutama bagi para tenaga pendidik yang belum begitu pakar dalam menggunakan kedua aplikasi ini. Sehingga, pendistribusian tugas dan penilaian terhadap tugas siswa masih dilakukan secara manual dimana siswa diminta datang ke sekolah satu kali dalam seminggu untuk mengambil tugas sekolah dan kemudian mengembalikan lagi tugas yang diberikan itu pada waktu yang telah ditentukan oleh guru.

Oleh karena itu, dalam kesempatan ini tim pengabdian melakukan pelatihan penggunaan Google Classroom dan Google Meet untuk digunakan dalam pembelajaran daring/ online selama pandemi Covid- 19 ini. Pelatihan ini ditujukan untuk guru- guru yang mengajar di Sekolah Dasar Islam Terpadu ALIF yang berlokasi di jalan Polonia Gang A No.3 Medan. Dengan dilaksanakannya pelatihan ini, guru- guru lebih aktif lagi dalam memanfaatkan aplikasi Google Classroom dan Google Meet selama pembelajaran jarak jauh dimasa pandemic Covid- 19 ini.

\subsection{Tujuan Kegiatan}

Tujuan kegiatan ini adalah untuk melatih guru- guru SDIT Alif dalam memanfaatkan aplikasi Google Classroom dan Google Meet sehingga dapat digunakan secara efektif dan maksimal dalam proses pembelajaran jarak jauh selama masa pandemic Covid- 19 ini.

\subsection{Manfaat Kegiatan}

Manfaat yang diharapkan dari kegiatan ini adalah para guru yang mengajar di SDIT Alif semakin mahir dalam menggunakan aplikasi Google Classroom dan Google Meet ini sehingga semakin terbantu dalam memberikan tugas dan melakukan penilaian kepada para siswa selama pembelajaran daring ini.

\subsection{Luaran Pengabdian Masyarakat}

Target luaran Pengabdian Kepada Masyarakat ini adalah sebagai berikut:

a. Para tenaga pendidik di SDIT Alif memahami dan mampu menggunakan aplikasi Google Classroom dalam pemberian tugas dan penilaian terhadap tugas para siswa secara efektif.

b. Para tenaga pendidik di SDIT Alif memahami dan mampu menggunakan dengan baik aplikasi Google Meet dalam menyampaikan materi ajar selama pembelajaran jarak jauh dimasa pandemic Covid-19 ini.

\section{Realisasi Kegiatan}

\subsection{Bentuk Kegiatan, Jadwal dan Tempat Kegiatan}

\section{a. Metode Pelaksanaan Kegiatan}

Pelatihan penggunaan Google Classroom dan Google Meet yang dilaksanakan di SDIT Alif Medan ini dilaksanakan dengan metode ceramah, diskusi dan praktik. Metode ceramah digunakan untuk menjelaskan mengenai manfaat dan penggunaan aplikasi Google Classroom dan Google Meet. Sedangkan metode diskusi digunakan untuk sesi tanya jawab seputar penggunaan Google Classroom dan Google Meet. Dan metode praktik adalah saat dimana para peserta pelatihan mempraktekkan hal- hal yang sudah dijelaskan dengan menggunakan laptop yang telah 
dipersiapkan sebelumnya. Sedangkan tim pengabdian mengamati perkembangan praktik yang dilakukan oleh para tenaga pendidik SDIT Alif.

\section{b. Waktu Efektif Pelaksanaan Kegiatan}

Kegiatan Pelaksanaan Pengabdian Kepada Masyarakat ini akan dilaksanakan pada Tanggal 03 Juli 2021 sebelum tahun ajaran baru dimulai.

\section{c. Tempat Kegiatan}

Dikarenakan materi yang akan disampaikan tidak memungkinkan disampaikan secara virtual karena dianggap tidak efektif, maka Kegiatan Pelatihan ini diadakan di secara tatap muka langsung di SDIT Alif yang berada di jalan Polonia Gang A No. 3 Medan, dengan menerapkan protokol kesehatan.
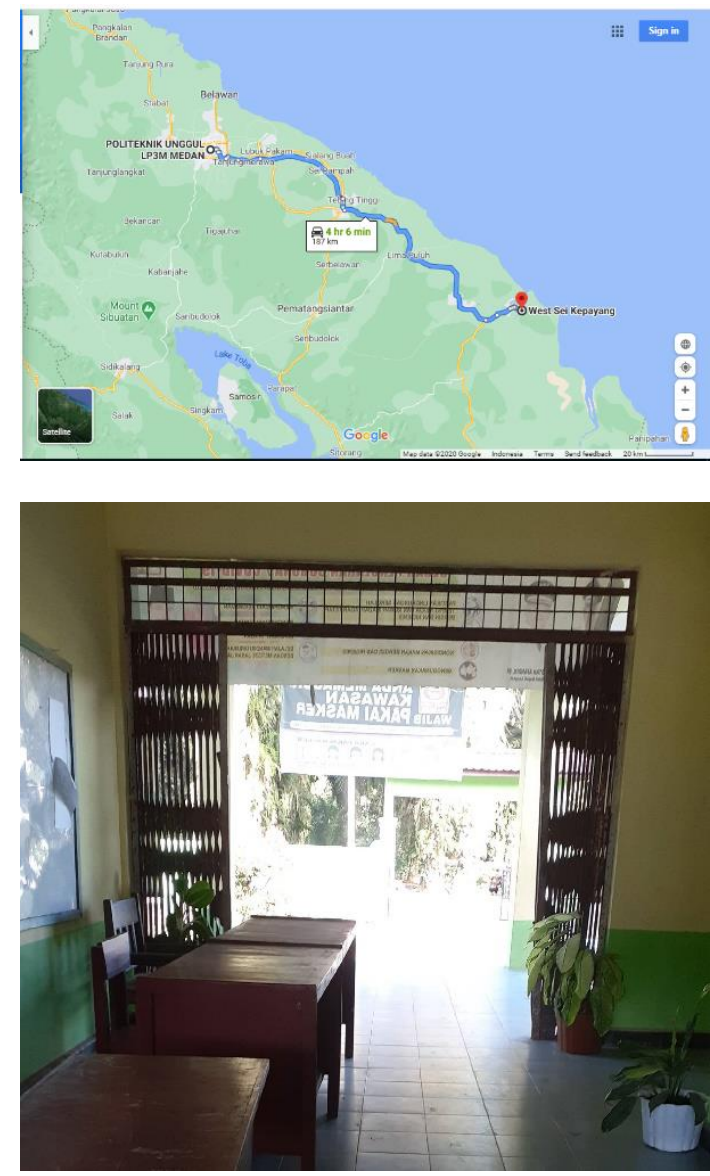

\subsection{TIM Pelaksana Pengabdian dan TUPOKSI serta (Jam dan hari)}

\section{a. Susunan TIM Pengabdian}

\begin{tabular}{|l|l|l|l|}
\hline No & Nama & NIDN & Dosen \\
\hline 1 & Cici Handayani, S.S.,M.Hum & 0101098001 & Dosen Bahasa Inggris \\
\hline 2 & Muhammad Fathoni, S.Si.,M.Si & 0127038102 & Dosen IImu Komputer \\
\hline 3 & Sharina Amanda, S.S.,M.Si & 0107078801 & Dosen Bahasa Indonesia \\
\hline 4 & Dewi Wulandari, S.Pd.,M.Hum & 0107088405 & Dosen Bahasa Inggris \\
\hline 5 & Zakia Fadila,S.E.,M.Ak & 0122018201 & Dosen Akuntansi \\
\hline
\end{tabular}

b. Tugas Pokok serta Peran setiap TIM Pengabdian

\begin{tabular}{|c|c|c|}
\hline Rincian Tugas & Waktu & \multicolumn{1}{c|}{ Pemateri } \\
\hline Pembukaan & $09.00-10.00$ WIB & Sharina Amanda, S.S.,M.Si \\
\hline
\end{tabular}




\begin{tabular}{|l|c|l|}
\hline \multicolumn{1}{|c|}{ Rincian Tugas } & Waktu & \multicolumn{1}{c|}{ Pemateri } \\
\hline $\begin{array}{l}\text { Pengantar Materi Google } \\
\text { Classroom }\end{array}$ & $10.00-11.00$ WIB & Cici Handayani, S.S.,M.Hum \\
\hline Pengantar Materi Google Meet & $11.00-12.00$ WIB & Dewi Wulandari, S.Pd.,M.Hum \\
\hline ISOMA & $\mathbf{1 2 . 0 0 - 1 3 . 0 0 ~ W I B ~}$ & \\
\hline Praktik Penggunaan Google Meet & $13.00-14.00$ WIB & Muhammad Fathoni, S.Si.,M.Si \\
\hline $\begin{array}{l}\text { Praktik Penggunaan Google } \\
\text { Classroom }\end{array}$ & $14.00-16.00$ WIB & Muhammad Fathoni, S.Si.,M.Si \\
\hline $\begin{array}{l}\text { Penutupan dan Pemberian } \\
\text { Cenderamata }\end{array}$ & 16.00 s/d Selesai & Zakia Fadila,S.E.,M.Ak \\
\hline
\end{tabular}

\subsection{Ringkasan/Garis-garis besar Materi}

\section{a. Materi Google Classroom}

Google Classroom adalah platform gratis berbasis web yang dibuat untuk mempermudah kegiatan pembelajaran pendidik dan murid. Google Classroom memungkinkan para guru untuk mengatur dan menilai progres murid-muridnya sambil tetap terhubung dari mana pun juga. Para murid bisa menerima dan mengumpulkan tugas secara langsung melalui Google Classroom, begitu juga para guru. Layanan ini sangat mengurangi penggunaan kertas dan mempermudah proses pembelajaran, terutama dalam proses pembelajaran jarak jauh.

Cara login ke Google Classroom:

- Buka classroom.google.com, lalu klik Buka Classroom.

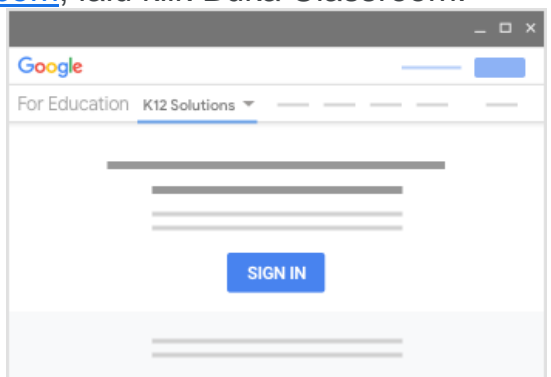

- Masukkan alamat email akun Classroom Anda, Ialu klik Berikutnya.

\section{Google}

\section{Sign in}

with your Google Account

Email or phone

Forgot email?

Learn more

Create account 
- Masukkan sandi, lalu klik Berikutnya.

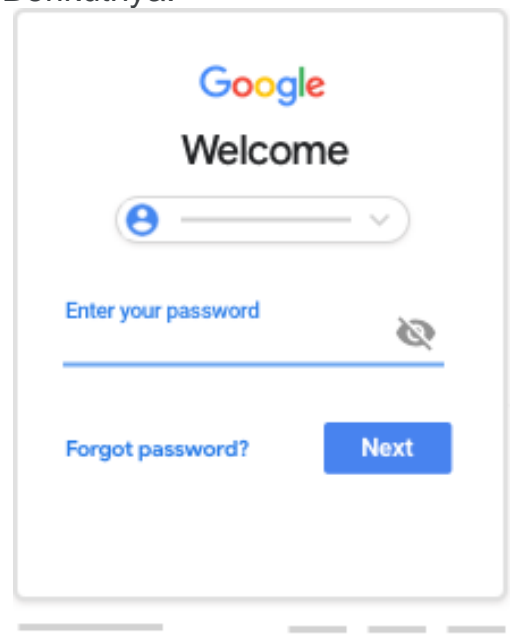

- Jika ada pesan selamat datang, tinjau pesan tersebut, lalu klik Terima.

- Jika Anda menggunakan akun Google Workspace for Education, klik Saya Seorang Siswa atau Saya Seorang Pengajar.

Tips: Pengguna dengan Akun Google pribadi tidak akan melihat opsi ini.

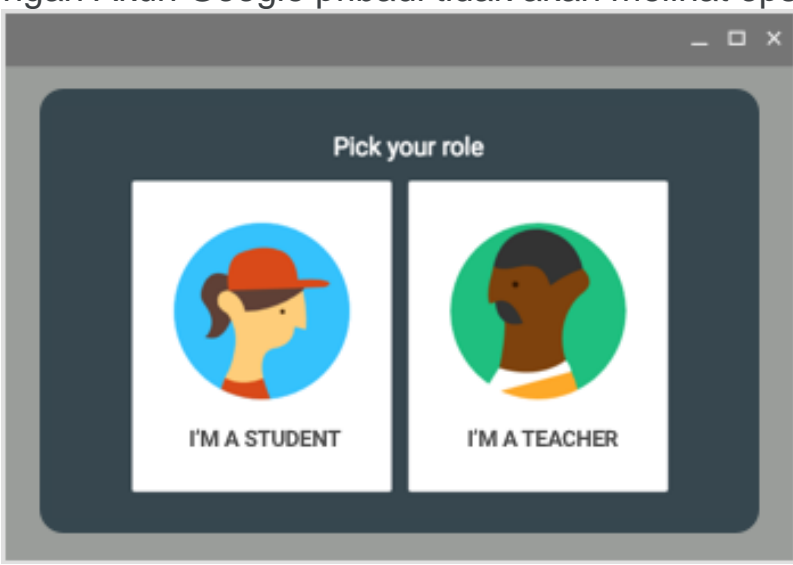

- Klik Mulai.

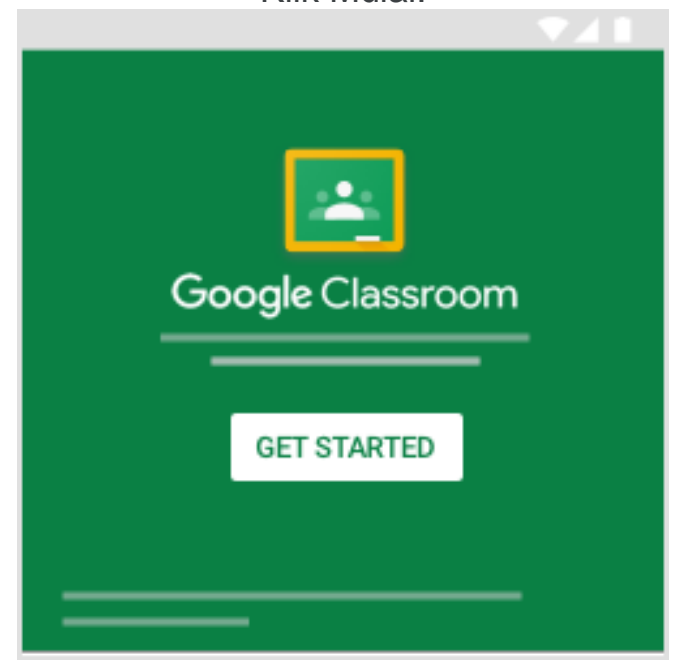




\section{b. Materi Google Meet}

Google Meet adalah aplikasi video conference gratis yang dapat digunakan melalui browser dan aplikasi smartphone. Aplikasi yang sebelumnya bernama Hangouts ini menawarkan fitur gratis yang lebih menarik dibanding aplikasi lainnya dengan batas waktu meeting dengan maksimum 100 peserta selama 60 menit. Ada beberapa paket dan harga untuk kamu yang membutuhkan kapasitas dan durasi meeting yang lebih lama. Berikut ringkasan harga dan paket dari Google Meet:

- Gratis: Semua pengguna Google dapat menggunakan layanan Google Meet secara gratis dengan batas waktu meeting 60 menit dengan hingga 100 peserta.

- Google Workplace Essentials (\$8 per pengguna per bulan): Menambahkan durasi meeting hingga 300 jam dengan batas 150 peserta. Paket ini menyediakan fitur simpan rekaman meeting otomatis ke Google Drive yang sudah di-upgrade ke 100GB dengan dukungan layanan pelanggan 24 jam.

- Google Workplace Enterprise (harga khusus per perusahaan): Menambahkan durasi meeting hingga 300 jam dengan batas 250 peserta. Selain menambahkan kapasitas Google Drive menjadi unlimited, paket ini juga mendukung live streaming ke 100.000 penonton dan berbagai fitur keamanan data lainnya lengkap dengan dukungan layanan pelanggan 24 jam.

Penggantian nama dilakukan oleh Google secara terselubung pada bulan Maret 2017. Pada awalnya, Google Meet ditargetkan sebagai Hangout versi bisnis, dan lebih cocok untuk penggunaan dalam sebuah perusahaan. Tapi sekarang Google Meet dapat diakses oleh semua pengguna Google, dan jumlah pengguna tiap harinya terus meningkat. Cara menggunakan Google Meet di PC atau laptop sangat mudah, karena kamu dapat menggunakan browser yang sudah terpasang seperti Google Chrome, Microsoft Edge, Opera, Firefox, Safari dan sebagainya. Berikut langkah-langkah menggunakan Google Meet di browser PC atau laptop:

1. Buka halaman Google Meet

Untuk menggunakannya, pertama-tama kamu tentu harus membuka Google Meet pada web browser-mu.

2. Login ke akun Google

Langkah selanjutnya, login ke akun Google yang kamu miliki. Pastikan alamat email dan password-nya sudah benar ya!

3. Pilih New Meeting untuk memulai video conference baru

Setelah berhasil login, kamu sudah bisa menggunakan Google Meet. Klik 'New Meeting' untuk memulai video conference baru.

4. Masukkan link / kode meeting untuk bergabung ke video conference yang sudah ada Atau jika kamu ingin bergabung ke video conference yang sudah ada, tinggal masukkan link atau kode meeting pada kolom yang tersedia. Setelah itu klik 'Join'.

5. Lakukan pengaturan kamera dan mikrofon

Jangan lupa lakukan pengaturan pada kamera dan mikrofon. Klik pada tombol pengaturan pada bagian bawah layar video conference.

6. Selesai!

Selain cara menggunakan Google Meet yang sangat mudah dan praktis, kamu juga dapat menggunakan berbagai fitur yang pada umumnya ditemukan di aplikasi yang perlu kamu download terlebih dahulu. Fitur-fitur di Google Meet browser ini meliputi:

- Background virtual

- Chat di dalam meeting

- Presentasi atau screen sharing

- Transkrip atau caption

- Whiteboard Dengan Google Jamboard 


\subsection{Masyarakat Sasaran}

Peserta pelatihan ini adalah guru/ tenaga pendidik yang mengajar di SDIT Alif yang berjumlah 9 (Sembilan) orang.

\section{Tinjauan Hasil yang Dicapai}

Kegiatan pelatihan penggunaan Google Classroom dan Google Meet telah dilaksanakan di SDIT Alif Medan dengan melibatkan guru/ tenaga pengajar yang mengajar di SDIT Alif sebagai peserta pelatihan. Berdasarkan hasil pengamatan setelah dilakukan pelatihan, para guru/ tenaga pengajar telah mampu menggunakan aplikasi Google Classroom dan Google Meet dengan efektif dalam proses pembelajaran jarak jauh selama masa pandemic yang belum berakhir ini. Diharapkan dengan menerapkan kedua aplikasi ini dalam sistem pembelajaran daring/ online, para guru/ tenaga pengajar semakin terbantu dalam memberikan tugas dan penilaian kepada para siswa sehingga para guru tidak perlu lagi mengumpulkan tugas dan menilai tugas para siswa secara manual yang dianggap tidak efektif dan cukup merepotkan.

\section{Daftar Pustaka}

Adams, Barry. (2020). GOOGLE CLASSROOM FOR TEACHERS: The Ultimate Step by Step Guide to Setup Your Virtual Classroom with Tips and Tricks and the Benefits from Distance Learning for Students and Teachers

Brock, Annie. (2020). Introduction to Google Classroom. Ulyssses Press. Berkeley.

Riyanti, Minik. (2020). Cara Praktis Menggunakan Google Classroom. CV.Budi Utama. Sleman

Amalia, Swita. (2019). PEMANFAATAN GOOGLE CLASSROOM SEBAGAI MEDIA PEMBELAJARAN ONLINE DI UNIVERSITAS DIAN NUSWANTORO.Jurnal IImiah IImu Komunikasi 18(2):225-233.https://doi:10.32509/wacana.v18i2.924

Setyo, Indrianto. (2021). Pembelajaran Dalam Jaringan (Daring) di Era Digital Dengan Google Suit. Ahlimedia Press.Malang.

Ruth, Oloruntobi. (2020). Google Meet User Guide: A Simple Guide on How to Safely Use the Google Meet Video Meetings for Businesses and Teams. Amazon Digital Services LCC. United States.

Sudarmanto, Eko. (2020). Konsep Dasar Pengabdian Kepada Masyarakat: Pembangunan dan Pemberdayaan. Yayasan Kita Menulis. Jakarta

Herwina, Wiwin. (2021). Analisis Model- Model Pelatihan. CV.Bayfa Cendekia Indonesia. Madiun. 


\section{Daftar hadir}

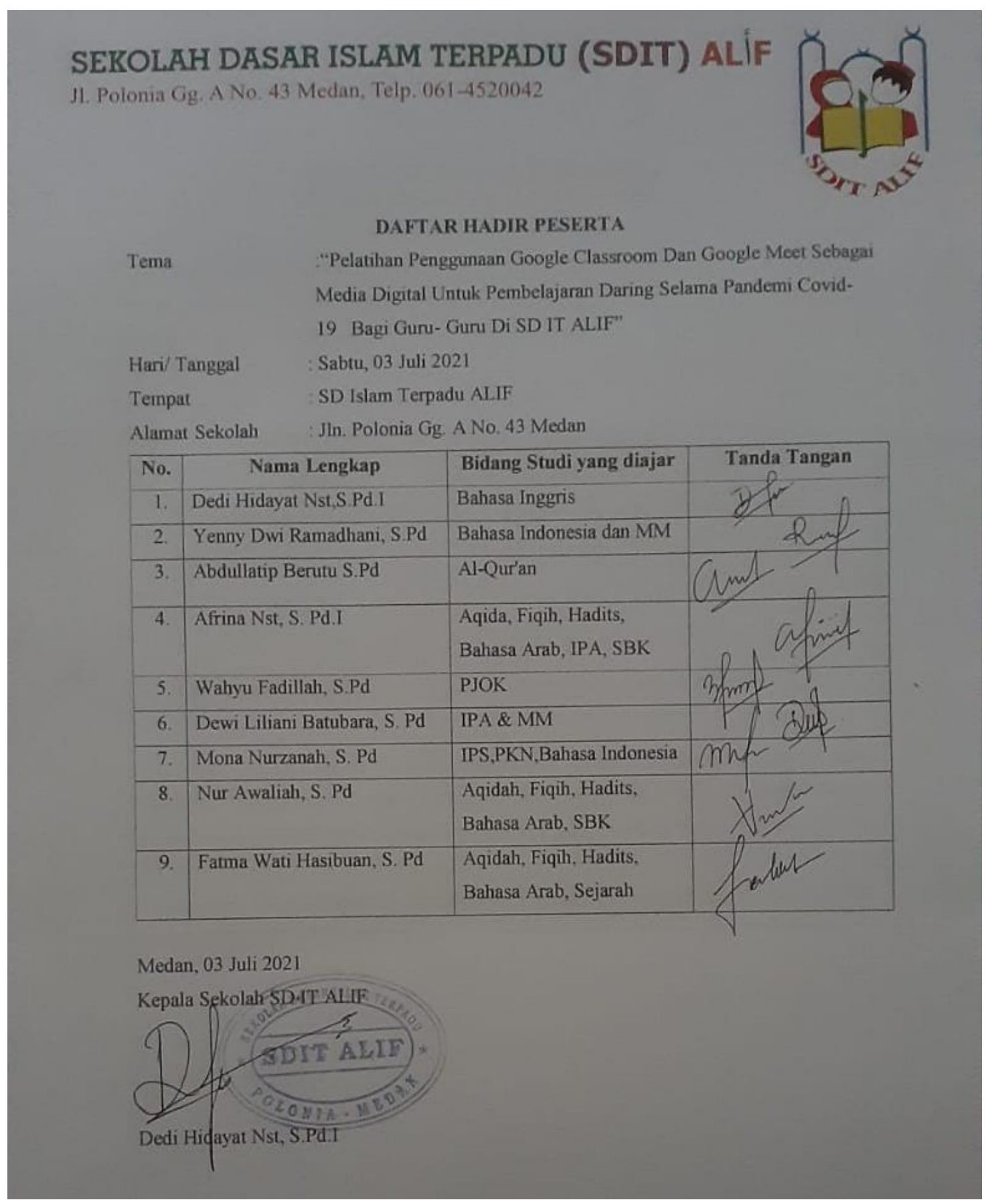

Pelatihan Penggunaan Google Classroom Dan Google Meet Sebagai Media Digital Untuk Pembelajaran Daring Selama Pandemi Covid-19 Bagi Guru-Guru Di SDIT ALIF (Cici Handayani, dkk) 


\section{Surat Keterangan}

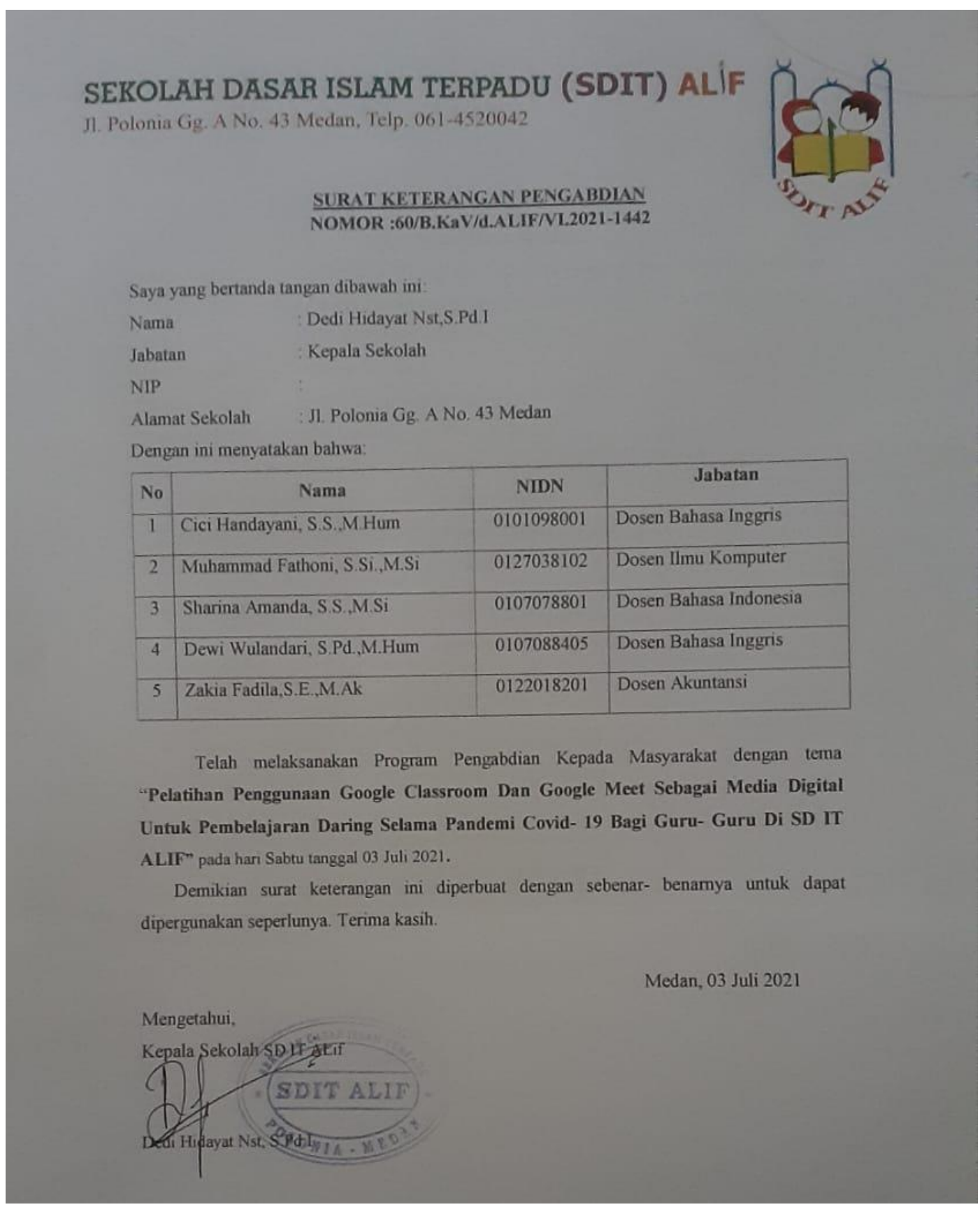




\section{Dokumentasi}

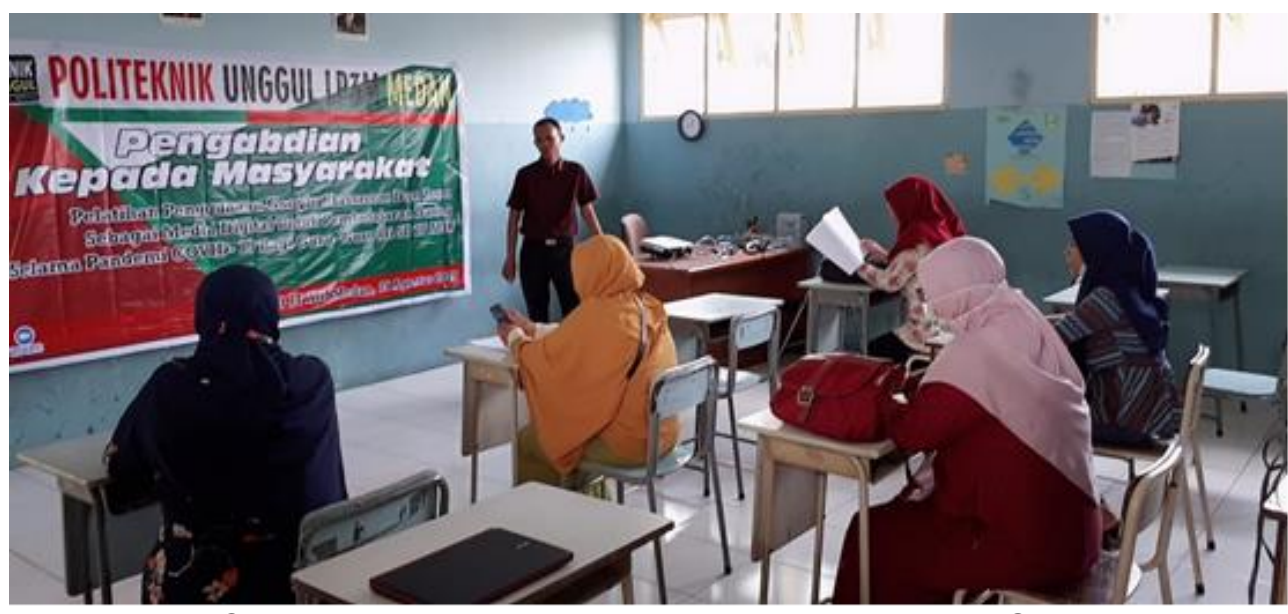

Gambar 1. Anggota Pengabdian Memberikan Kata Sambutan

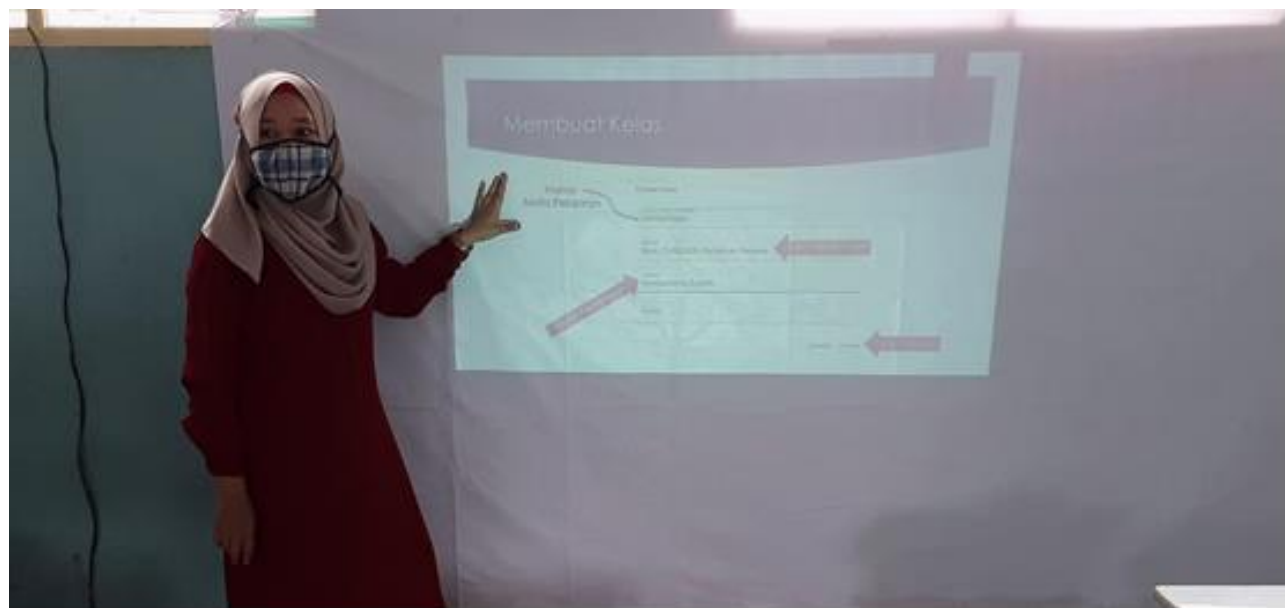

Gambar 2. Anggota Pengabdian Memberikan Pelatih

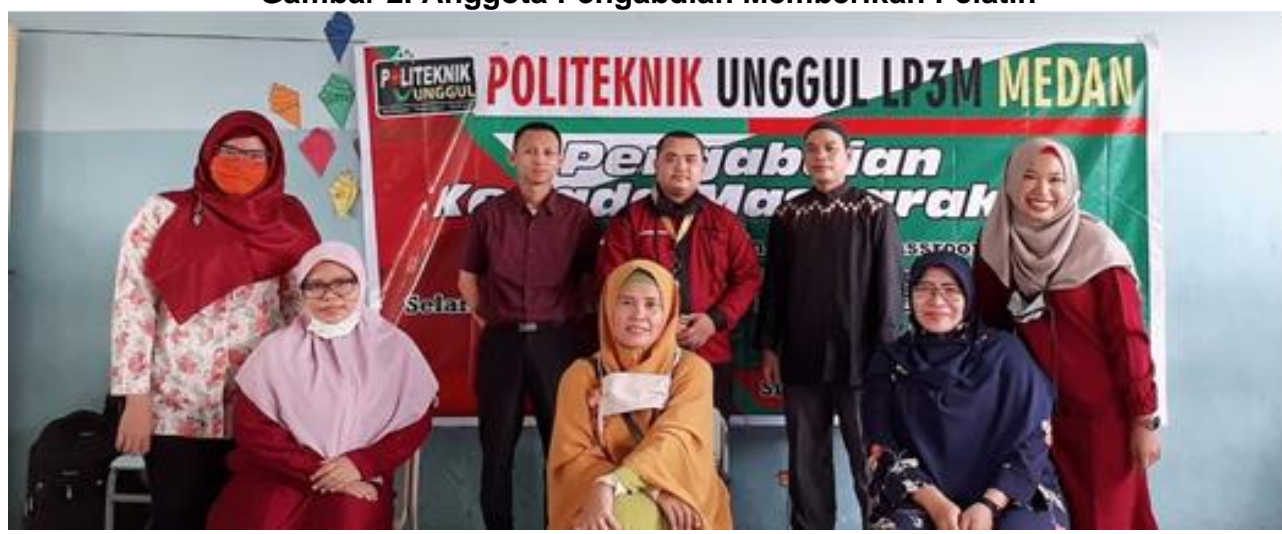

Gambar 3. Tim Pengabdian bersama Kepala Sekolah 